\title{
Personal Profile of the Beneficiaries of Agriculture Technology Management \& Quality Improvement Centreof SKNAU Jobner
}

\author{
Pushpa Kumawat $^{1 *}$, J. P. Yadav², Tribhuwan Singh Rajpurohit ${ }^{3}$, \\ Sarjeet Singh ${ }^{4}$ and Neelesh Raghuwanshi ${ }^{4}$ \\ ${ }^{1}$ Krishi Vigyan Kendra, Nagaur-I, India \\ ${ }^{2}$ Department (Extension Education), ${ }^{3}$ (Extension Education), CSSRI, CCSHAU Hisar, India \\ ${ }^{4}$ (Extension Education), S.K.N.C.O.A., Jobner Jaipur, India \\ *Corresponding author
}

A B S T R A C T

\section{Ke y w o r d s \\ ATMQIC, \\ Beneficiaries, \\ RKVY, \\ Programmes, \\ Production, \\ Agriculture \\ Article Info \\ Accepted: \\ 23 April 2020 \\ Available Online: \\ 10 May 2020}

\begin{abstract}
ATMQIC project was started to provide the facility of a 'single window' approach. The kind of information and the way it is to be used are critical factor to the growth of agriculture. The present study was conducted in three selected villages' viz., I Dhan Ka bas of Panchayat Samiti Dudu and khejrawas, Dhani Boraj of Panchayat Samiti Sambhar Lake of district Jaipur, Rajasthan. Where the ATMQIC project was only introduced and implemented the activities related to agriculture. Out of prepared list of total beneficiaries of ATMQIC, 120 respondents were selected from these selected villages through proportional allocation to the size of the population. The results of the research indicated that majority of respondents (64) were belonged to adult age group (53.33 per cent), (87) of ATMQIC were from OBC caste (72.50 per cent), 25.83 per cent (31) were educated upto middle, 53 (44.17) per cent respondents of ATMQIC were having 1-2.5 ha. Landholding and majority of the respondents belonged to large family size constituted 70.83 per cent (85) of the total sample.
\end{abstract}

\section{Introduction}

The cornerstone of India's agricultural revolution has been the availability of improved varieties of cereals, oilseeds, and pulses etc., breeds of livestock including poultry and fisheries, horticultural plant materials, and improved management practices for increasing the productivity, sustainability and stability of various crops and livestock enterprises. This has raised the search by farmers for future availability of seeds, planting materials and other materials, easy accessibility to diagnostic services for soil fertility and plant protection, availability of appropriate information through leaflets, pamphlets and increased scope in sale of consultancy services. 
Often the farmers are not aware of as to whom and where to approach for field problems. It is felt that the facility of a single window $^{\text {ee }}$ approach at the entrance of the Indian Council of Agriculture Research (ICAR) Institute/ State Agricultural Universities (SAUs) will enable the farmers to have the required information for the solution to their problems related to the areas in which the concerned institute is involved. Because of the dominance of small and resource poor farmers and concentration of poor people in several sectors, public institutions like ICAR Institutes and SAUs will continue to play a vital role in supply of information for increasing the overall productivity in agriculture. Government of India has started a number of programmes related to Agriculture growth which includes: KVK, IRDP, NREP, NABARD, RLEGP, CIS, TMO, SFPP, JRY, IVLP, SJSRY, NATP, KCC, JGSY, NAIS, PGSY, SGRY, NFWP, NAIP, NFSM, and RKVY to enhance Agriculture production strengthening of regional research stations, Krishi Vgyan Kendra of SAUs by providing funds for infrastructural development as well as for transfer of technology to the farmers.

There are so many programmes initiated by Government of India: These programmes increase Agriculture growth and help the farmer to increase the Agriculture production. Out of them Rashtriya Krishi Vikas Yojana is one of the important programmes for agriculture development. The Agriculture Technology Management \& Quality Improvement Centre (ATMQIC) project was one of them submitted under RKVY to the Department of Agriculture, Govt. of Rajasthan. ATMQIC project was started to provide the facility of a 'single window' approach at the entrance of the SKNAU, Jobner which enables the farmers to have the required information for the solution to their problems related to the areas in which institute is involved. Because of the dominance of small and resource poor farmers and concentration of poor people in several sectors, SKNAU, Jobner continues to play a vital role in supply of information for increasing the overall productivity in agriculture.

\section{Materials and Methods}

The present study was conducted in Jaipur district of Rajasthan. The district Jaipur was selected purposely because the ATMQIC project was only introduced and initiated the activities related to agriculture in the selected area of Jaipur district. As the district Jaipur comprises 15 Panchahyat Samiti's, but the ATMQIC project activities were implemented in the selected villages of Panchayat Samiti of Sambhar Lake and Dudu. Therefore Panchahyat Samiti's Sambhar Lake and Dudu were selected purposely.

The ATMQIC project was operated in the three selected villages namely I Dan Ka Bas, Khejravas, Dhani Boraj and various activities of the project were implemented in the selected villages. Hence, these three villages were selected for the study purpose. A list of all the respondents/ farmers of three selected villages that has been benefited under ATMQIC was prepared with the help of ATMQIC project staff and 120 beneficiaries were selected from these selected villages randomly through proportional allocation to the size of the population. The ex post facto research design was adopted, since the phenomenon has already occurred and is continuing. An interview schedule was developed in accordance with the objectives of the study and it was pre tested and translated into Gujarati. The data of this study were collected with the help of structural interview schedule. The collected data were classified, tabulated, analyzed and interpreted in order to make the findings meaningful. 
Table.A Selection of respondents of ATMQIC

\begin{tabular}{|c|c|c|c|}
\hline $\begin{array}{l}\text { Name of selected Panchayat } \\
\text { Samiti }\end{array}$ & $\begin{array}{c}\text { Name of } \\
\text { selected villages }\end{array}$ & $\begin{array}{l}\text { Total no. of } \\
\text { beneficiaries }\end{array}$ & $\begin{array}{l}\text { No. of selected } \\
\text { respondents }\end{array}$ \\
\hline Dudu & I Dhan Ka Bas & 140 & 60 \\
\hline Sambhar Lake & Dhani Boraj & 80 & 34 \\
\hline Sambhar Lake & Khejrawas & 60 & 26 \\
\hline \multicolumn{2}{|l|}{ Total } & 280 & 120 \\
\hline
\end{tabular}

\section{Results and Discussion}

To study the selected characteristics of the respondents was one of the objectives under study. On the basis of review of literature, some independent variables were selected under study like age, cast, education, landholding and size of family. The findings of these characteristics were presented in the following sections.

\section{Personal profile of the respondents}

\section{Age}

On the basis of classification given by ministry of Agriculture and Cooperation, Government of India, the respondents were classified into three categories i.e. young (below 18-35 years), adult (from 36 to 55 years) and old (above 55 years). The distribution of respondents with respect to their age has been presented in Table 1 and diagrammatically in Figure 1.

The data given in table 1 show that majority of respondents (64) were belonged to adult age group (53.33 per cent) followed by young (39) and old (17) age group with 32.50 and 14.17 per cent, respectively. This finding is in conformity with the finding of Prajapati (1997), Gangaiah et al., (2006), Soni (2009), Kumar (2009) and Naik et al., (2012). The data given in table 2 reveal that majority of the respondents (87) were from other backward class category (72.50 per cent) followed by general (14), scheduled caste (10) and scheduled tribes (9) categories with
$11.67,8.33$ and 7.50 per cent, respectively. The data also presented through diagrammatically in figure 2 . These finding are in support with findings of Nayak et al., (2014) Lenka and Behera (2015).

\section{Education}

The data incorporated in table 3 clearly show that out of the total 120 respondents, 25.83 per cent of the respondents (31) were educated up to middle, whereas 18.33 per cent (22) were primary school level and 17.50 per cent (21) upto higher secondary/ senior secondary level, 10.83 per cent (13) were graduate or above, 10.00 per cent (12) were can read only and 8.34 per cent respondents (10) were illiterate categories. The results were also shown by diagrams in figure 3 . These finding are in support with findings ofYaligar (1997) and Soni (2011).

\section{Landholding}

The data given in table 4 indicate that out of 120 respondents, 53 (44.17 per cent) farmers were having 1-2.5 ha. landholding, while 51 (42.50 per cent) farmers were having less than 1 ha. Landholding, 7 (5.83 per cent) farmers were possessed 2.6-4.0 ha. landholding, 3 (2.50 per cent) farmers were having 4.1-6.0 ha. landholding, 2 (1.67 per cent) farmers were having 6.1-8.0 ha. landholding, 2 (1.67 per cent) farmers were having 8.1-10.0 ha. landholding and 2 (1.66per cent) farmers were having more than 10.0 ha. landholding. The results were also presented diagrammatically in figure 4 . 
Table.1 Distribution of respondents according to their age $n=120$

\begin{tabular}{|c|l|c|c|}
\hline S No. & Age categories & Frequency & Percentage \\
\hline $\mathbf{1 .}$ & Young (18-35 years) & 39 & 32.50 \\
\hline $\mathbf{2 .}$ & Adult (36 to 55 years) & 64 & 53.33 \\
\hline $\mathbf{3 .}$ & Old (>55 years) & 17 & 14.17 \\
\hline Total & & $\mathbf{1 2 0}$ & $\mathbf{1 0 0 . 0 0}$ \\
\hline
\end{tabular}

Table.2 Distribution of respondents according to their caste $n=120$

\begin{tabular}{|c|l|c|c|}
\hline S No. & \multicolumn{1}{|c|}{ Category } & Frequency & Percentage \\
\hline $\mathbf{1 .}$ & Scheduled caste $(\mathrm{SC})$ & 10 & 8.33 \\
\hline $\mathbf{2 .}$ & Scheduled tribe $(\mathrm{ST})$ & 9 & 7.50 \\
\hline $\mathbf{3 .}$ & Other backward class (OBC) & 87 & 72.50 \\
\hline $\mathbf{4 .}$ & General (GEN) & 14 & 11.67 \\
\hline Total & & $\mathbf{1 2 0}$ & $\mathbf{1 0 0 . 0 0}$ \\
\hline
\end{tabular}

Table.3 Distribution of respondents according to their education $n=120$

\begin{tabular}{|c|l|c|c|}
\hline S No. & Education Categories & Frequency & Percentage \\
\hline $\mathbf{1 .}$ & Illiterate & 10 & 8.34 \\
\hline $\mathbf{2 .}$ & Can read only & 12 & 10.00 \\
\hline $\mathbf{3 .}$ & Primary & 22 & 18.33 \\
\hline $\mathbf{4 .}$ & Middle & 31 & 25.83 \\
\hline $\mathbf{5 .}$ & Secondary school & 11 & 9.17 \\
\hline $\mathbf{6 .}$ & Higher secondary/Senior Secondary & 21 & 17.50 \\
\hline $\mathbf{7 .}$ & Graduate/Above & 13 & 10.83 \\
\hline Total & & $\mathbf{1 2 0}$ & $\mathbf{1 0 0 . 0 0}$ \\
\hline
\end{tabular}

Table.4 Distribution of respondents according to their size of landholding $n=120$

\begin{tabular}{|c|l|c|c|}
\hline S No. & Landholding Categories & Frequency & Percentage \\
\hline $\mathbf{1 .}$ & No land & 0 & 0.00 \\
\hline $\mathbf{2 .}$ & Less than 1 ha & 51 & 42.50 \\
\hline $\mathbf{3 .}$ & $1-2.5$ ha & 53 & 44.17 \\
\hline $\mathbf{4 .}$ & $2.6-4.0$ ha & 7 & 5.83 \\
\hline $\mathbf{5 .}$ & $4.1-6.0$ ha & 3 & 2.50 \\
\hline $\mathbf{6 .}$ & $6.1-8.0$ ha & 2 & 1.67 \\
\hline $\mathbf{7 .}$ & $8.1-10.0$ ha & 2 & 1.67 \\
\hline $\mathbf{8 .}$ & More than 10 ha & $\mathbf{1 2 0}$ & 1.66 \\
\hline Total & & & $\mathbf{1 0 0 . 0 0}$ \\
\hline
\end{tabular}

Table.5 Distribution of respondents according to their size of family $n=120$

\begin{tabular}{|c|c|c|c|}
\hline S No. & Size of family categories & Frequency & Percentage \\
\hline 1. & Small (Upto 5 Member) & 35 & 29.17 \\
\hline 2. & Large (More than Five Member) & 85 & 70.83 \\
\hline & $\begin{array}{lll}\text { Total }\end{array}$ & 120 & 100.00 \\
\hline
\end{tabular}




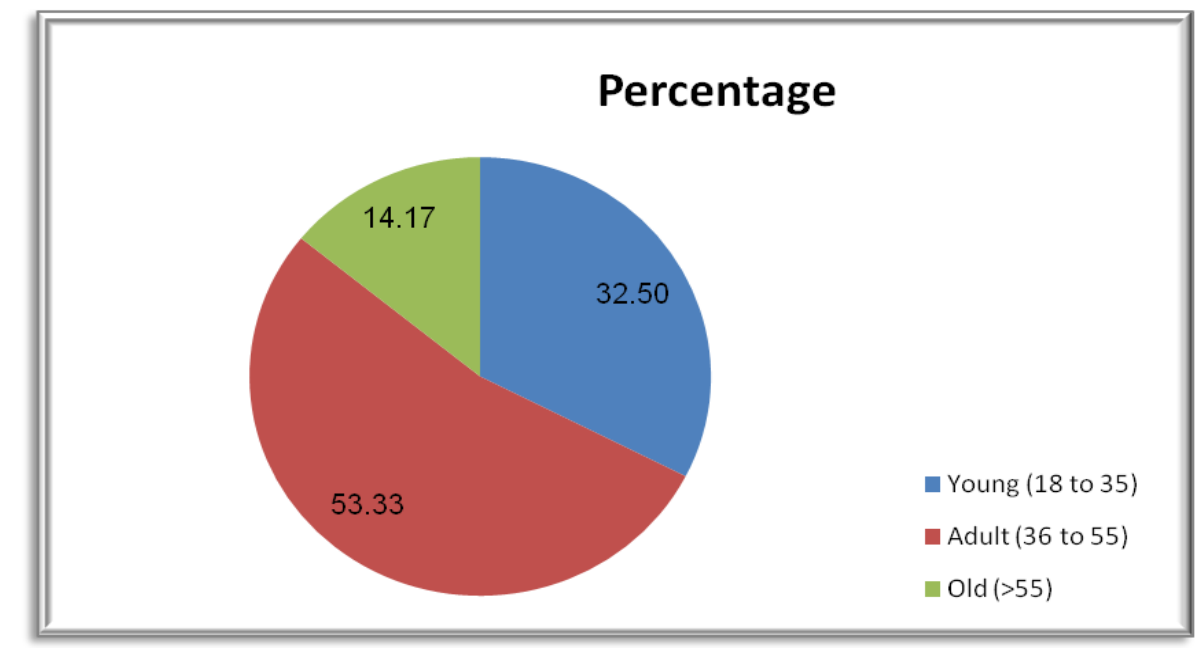

Fig.1 Distribution of respondents according to their age

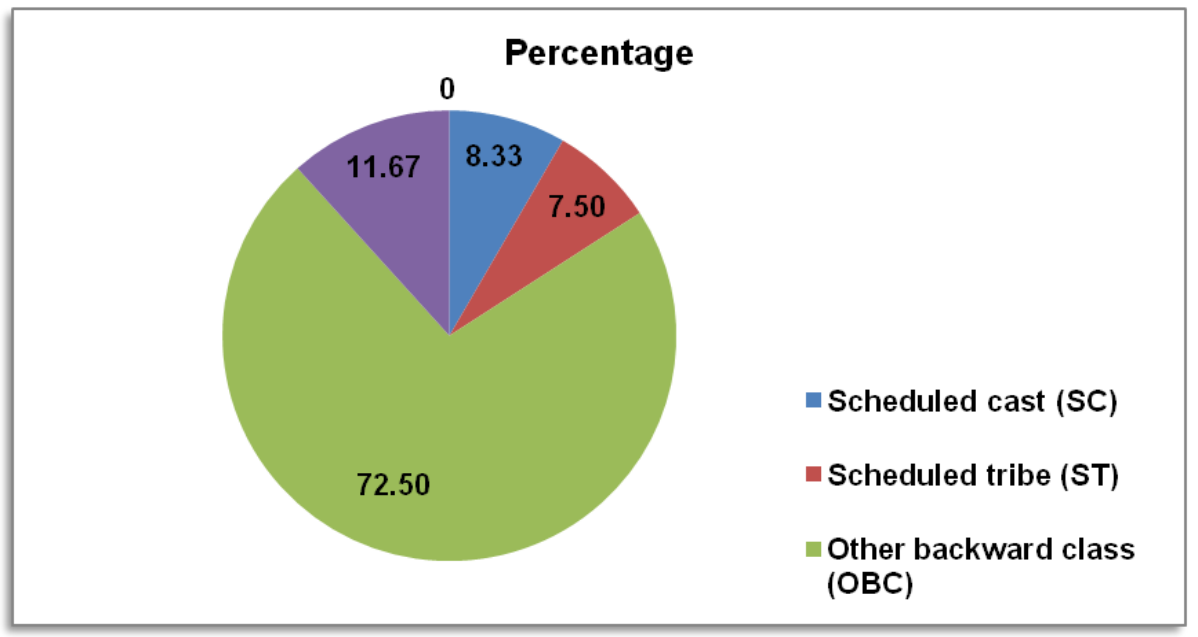

Fig.2 Distribution of respondents according to their caste

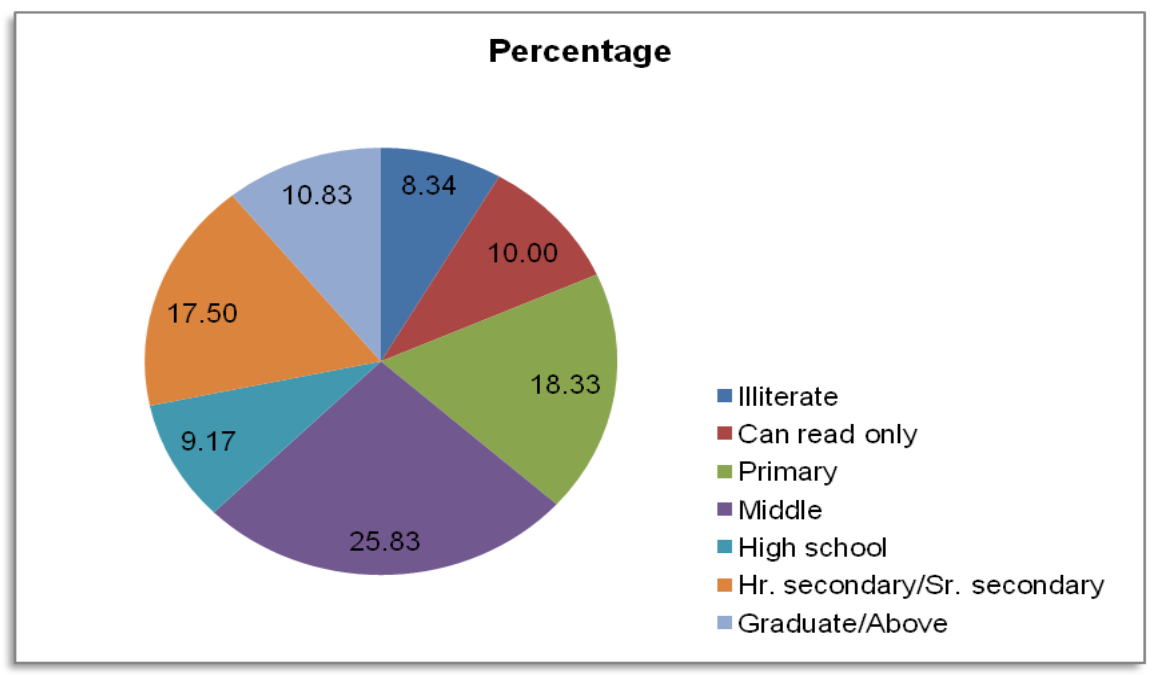

Fig.3 Distribution of respondents according to their education 


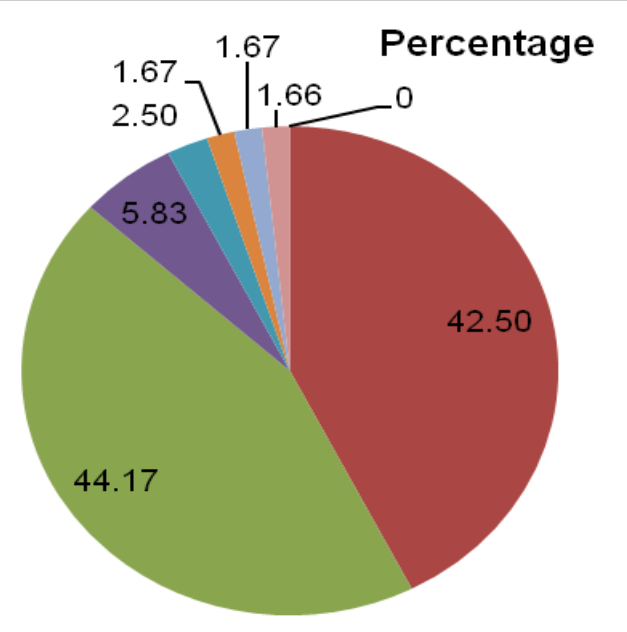

Noland

- Less than 1 ha

-1-2.5 ha

-2.6- $4.0 \mathrm{ha}$

4.1-6.0 ha

$=6.1-8.0 \mathrm{ha}$

8.1-10.0 ha

More than 10 ha

Fig.4 Distribution of respondents according to their size of land holding

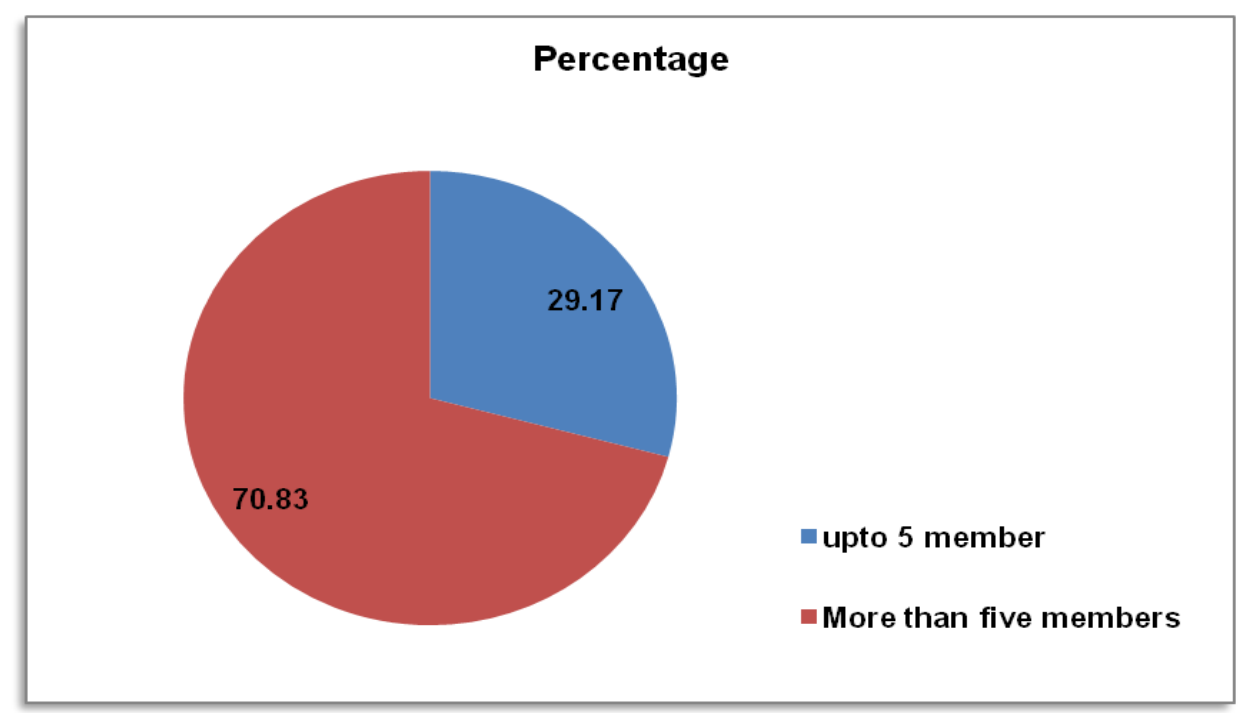

Fig.5 Distribution of respondents according to their size of family

Therefore, conclusion may be drawn from these findings that majority of the respondents were found in the category of having landholding upto 2.5 ha. This finding is in conformity with the finding of Yaligaz (1997), Mandloi (2012).

\section{Size of family}

The data given in table 5 reveal that majority of the respondents (85) belonged to large family size. This family size constituted 70.83 per cent of the total sample and 29.16 per cent respondents (35) were from small family size.
The results are also presented diagrammatically in figure 5. These finding are in support with findings of Satyawati et al., (1993) and Ahire et al., (2014).

It was found that Majority of the respondents of ATMQIC 64 (53.33 per cent) fell in medium age group followed by young (39) and old (17) age group with 32.50 and 14.17 per cent, respectively. It was found that Majority of the respondents (87) of ATMQIC were from $\mathrm{OBC}$ caste $(72.50$ per cent) followed by followed by general (14), scheduled caste (10) and scheduled tribes (9) 
categories with $11.67,8.33$ and 7.50 per cent, respectively. It was also found that majority of the respondents i.e. 25.83 per cent (31) were educated upto middle, whereas 18.33 per cent (22) were primary school level and 17.50 per cent (21) upto higher secondary/ senior secondary level, 10.83 per cent (13) were graduate or above, 10.00 per cent (12) were can read only and 8.34 per cent respondents (10) were illiterate categories.

It was found that majority of respondents 53 (44.17) per cent respondents of ATMQIC were having 1-2.5 ha. Landholding and 42.50 per centre respondents were having less than 1 ha. Landholding, 5.83 per cent respondents were possessed 2.6-4.0 ha. Landholding, 2.50 per centre respondents were having 4.1-6.0 ha. Landholding, 1.67 per cent respondents were having 6.1-8.0 ha. Landholdings, 1.67 per centre respondents were having 8.1-10.0 ha. landholding, whereas 1.66 per cent respondents were having more than 10.0 ha. landholding. It was found that majority of the respondents belonged to large family size. This family size constituted 70.83 per cent (85) of the total sample and 29.16 per cent respondents (35) were from small family size.

\section{References}

Ahire, M.C., Birari, D. and Kamble, D.K. (2007). Adoption of poultry management practices in Sholapur, India, The Asian Journal of Animal Science, 2 (1\&2): 55-58.

Amutha, 2011. Socio-economic impact through Self Help Groups. Journal of Economics and Sustainable Development. 2(6): 89-94.

Bariya, M. K. 2016. Impact of Self Help Groups promoted under integrated watershed management programme on empowerment of women. Ph. D. Thesis (Unpublished), Junagadh Agricultural University, Junagadh.
Debabrata, M. and Bandyopadhyay, A.K. (2013). Problem and prospect of National Rural Employment Guarantee Scheme in Jharkhand. Journal of Progressive Agriculture, 4 (1): 92-95.

Devalatha, C. M.; Hirevenkana Goudar, L. V. and Ramchandran, V. A. 2013. Socioeconomic and psychological status of self-help group members in Northen Karnataka. Agriculture Update. 8(3): 496-503.

Gangaiah, C.; Nagaraja, B. and Vasudevulu Naidu, C., 2006. Impact of Self-help groups on income and employment : A case study. Kurukshetra. 54(5): 18-23.

Geethanjali, R. and Prabhakar, K. 2013. Economic development of women through SHGs in YSR (Kadapa) District, Andhra Pradesh, India. Studies on home and community Science. 7(1): 25-34.

Kumar, Ankaiah K.; Eswarappa,G. and Narayana Swamy,B.K. (2008). Training to Stakeholders towards Agricultural Development and Rural Prosperity in ATMA. Paper Published in Golden Jubilee Celebration \& National Seminar on innovative extension strategies for Agricultural Development and Rural Prosperity organized by Department of Extension Education R.A.U.,Pusa Indian Society of Extension Education, New Delhi. pp:76-77.

Kumar,S. (2009). Technological gap in adoption of improved cultivation practices by the soybean growers. M.Sc. (Agri.) Thesis, Univ. Agric. Sci., Dharwad, Karnataka (India).

Kumar,S. (2009). Technological gap in adoption of improved cultivation practices by the soybean growers. M.Sc. (Agri.) Thesis, Univ. Agric. Sci., Dharwad, Karnataka (India).

Lenka, B., Behera, B.S. (2015), Study on Adoption of scientific poultry Management practices by farmers of 
Cuttack district of Odisha, International Journal of Social Relevance \& Concern (IJSRC) 3 (10)

Mandloi, Sunil (2012). A study on perception and usefulness of seed village programme for soybean crop among the beneficiary farmers of Indore block of Indore district (M.P.). M.Sc. (Ag) Thesis Submitted to the Rajmata Vijayaraje Scindia Krishi Vishwa Vidyalaya, Gwalior.

Naik, R. M.; Tandel, B. M. and Chauhan, N. M. 2012. Empowerment of rural women through SHGs. Agriculture Update. 7(3 \& 4): 342-345.

Nayak, S.K., Saxena, K.K. and Rai D.P. (2014), A Study on the Effect of Television in Comprehensive of Organic Farming Technology, Indian Journal of Extension Education, 50 (1\&2): 103-105.

Parmar, Lokendra (2014). An evaluation study of Farmers Field School on soybean management practices conducted by agriculture department of Tikamgarh district (Madhya Pradesh). M.Sc. (Ag) Thesis unpublished J.N.K.V.V. Jabalpur.

Prajapati,N.P. (1997). Role of demonstration in transfer of technology for pulses and oilseed crops among the farmers of Rewa and Satna districts (M.P.). M.Sc. (Ag.) Thesis , JNKVV, Jabalpur.

Satyawati, Sangvan, V.; Gandhi, S. and
Yadav, L. (1993). "Role of rural women in decision making for credit procurement". Kurukshetra. 13, (2): 3133.

Sazgaya, Chamanlal (2013). A study of Crop Insurance Scheme for Soybean Cultivation, Governed by Bank of India in Khandwa District of Madhya Pradesh. M.Sc. (Ag) Thesis Submitted to the Rajmata Vijayaraje Scindia Krishi Vishwa Vidyalaya, Gwalior.

Shelke, S. A.; Gohad, V. V. and Shinde, P. P. 2013. Knowledge of the members about working of the self-help groups. Agriculture Update. 8(4): 613-615.

Soni, A. N. 2009. Socio-economic change in rural tribal women through self-help groups. A seminar on participatory approach and recent trends in rural development, Junagadh 31st August 2009. Junagadh Agricultural University, Junagadh. pp: 19.

Soni, Monika (2011). A study on Agricultural Technology Management Agency (ATMA) Project in context to beneficiaries of soybean demonstration under Sanwer Block of Indore District, M.P. M.Sc. (Ag.) Thesis Submitted to the Rajmata Vijyaraje Scindia Krishi Vishwa Vidyalaya, Gwalior.

Yaligar,S.S.P. (1997). A study on soybean cultivation by farmers of Belgaum district an analytical study. M.Sc. (Agri) Thesis, Univ. Agric. Sci., Dharwad.

\section{How to cite this article:}

Pushpa Kumawat, J. P. Yadav, Tribhuwan Singh Rajpurohit, Sarjeet Singh and Neelesh Raghuwanshi. 2020. Personal Profile of the Beneficiaries of Agriculture Technology Management \& Quality Improvement Centreof SKNAU Jobner. Int.J.Curr.Microbiol.App.Sci. 9(05): 2758-2765. doi: https://doi.org/10.20546/ijcmas.2020.905.317 